\title{
Mystic Effects of Kisspeptin in Reproduction of Livestock
}

\author{
C.G. Shashank*, N. Anand Kumar and P.S. Banakar \\ ICAR-NDRI Karnal, Haryana-132001, India \\ *Corresponding author
}

\begin{abstract}
A B S T R A C T
Keywords

Kisspeptin, domestic animals, GnRH, GPR54, Growth Hormone

Article Info

Accepted:

10 June 2018 Available Online: 10 July 2018

The commencement of puberty has been interesting topic for reproductive endocrinologists for years. Yet its fundamental physiological mechanisms have stayed mysterious until recently. The findings and understanding of the effects put forth by the peptide hormone kisspeptin have shed light on this research area. Kisspeptin (Kp), a family of neuropeptides which is produced chiefly by neuronal clusters at discrete hypothalamic nuclei, are vital regulators of GnRH neurons. Studies have found a role for Kp to release growth hormone $(\mathrm{GH})$, prolactin and luteinizing hormone (LH) from cattle, rat and monkey pituitary cells. Kisspeptin neuronal system directs both pulsatile GnRH secretion that stimulates folliculogenesis, spermatogenesis and steroidogenesis and the GnRH surge that activates ovulation in females Kisspeptin and related substances could therefore be valuable for the development of novel strategies for the management of fertility in farm animals. To this end, the present review aimed to summarize the current research on kisspeptin and its importance in domestic animals.
\end{abstract}

\section{Introduction}

Kisspeptin (Kp), also known as Metastin is a neuropeptide, produced chiefly in the hypothalamus from Kiss1 gene, Kisspeptin is a peptide hormone comprised of 145-amino acid residues. Kisspeptin was discovered by Lee et al., (1996) who identified Kiss1 gene for inhibiting cancer cell metastasis in humans. Kiss1 was baptized for the home of the legendary Hershey chocolate Kiss (Hershey, Pennsylvania, USA) where the gene was discovered (Gottsch et al., 2004). Kp has also been caught up in the assimilation of metabolic control of reproduction where it stimulates gonadotropin-releasing hormone $(\mathrm{GnRH})$ release and subsequent secretion of

\section{luteinizing hormone. G-protein-coupled} receptor (Kiss1r or GPR54), a strong associated receptor of kisspeptin. Principally brain controls gonadal activities by synthesizing gonadotropin-releasing hormone $(\mathrm{GnRH})$ by neurons in the hypothalamus into the portal vessels. This GnRH acts on anterior pituitary to secrete gonadotropins, luteinizing hormone (LH) and follicle-stimulating hormone (FSH). Gonadotropins stimulate the gonads to secrete steroid hormones such as Estrogen and Progesterone in females and androgens in males. The significance of Kisspeptin and $\mathrm{G}$ protein-coupled receptor 54 concerning fertility was motioned by the seminal discovery in 2003 of human pedigrees with GPR54 mutations that failed to go 
through puberty (Seminara et al., 2003). Kisspeptin and GPR54 were identified within the brain stem, hypothalamus, pituitary, spinal cord, ovary, liver, prostate, pancreas, aorta, intestine, coronary artery, placenta and umbilical vein (Roseweir et al., 2009). Kisspeptin-GPR54 signaling is obligatory for the pubertal commencement of Gonadotropinreleasing hormone (GnRH) neurons and reproductive function, both of which play a vital role in the rheostat for the hypothalamic pituitary gonadal (HPG) axis encompassing follicular development, ovulation, spermatogenesis and steroidogenesis (Roseweir et al., 2009). The three most important components of HPG axis i.e. Hypothalamus, Anterior pituitary, and Gonads are linked via feed-forward loops whereby GnRH stimulates the secretion of gonadotropins and these, in turn, support gonadal maturation and function (Figure 1). This review aimed mainly to summarize the importance of kisspeptin in domestic animals.

\section{Kisspeptin action on LH and Gonadotropin}

In situ hybridization (ISH) and immunohistochemistry (IHC) are the foremost modus operandi for ascertaining GPR54, $\mathrm{GnRH}$ gene or protein expression and its localization. Kiss1 neurons were found in the Preoptic area (POA) and Arcuate nucleus (ARC) regions with a superior cell density in ARC by ISH in ewes (Smith et al., 2007). Kisspeptin fuels the release of $\mathrm{GnRH}$ and consequent secretion of LH. Intravenous administration of $\mathrm{Kp}-10$ to ovariectomized (OVX) ewes, stimulated the concentration of circulating $\mathrm{LH}$ and upsurge of $\mathrm{GnRH}$ concentrations in Cerebrospinal Fluid (CSF) (Caraty et al., 2007). Central administration of Kp-10 augmented GnRH concentrations in the cerebrospinal fluid and increased $\mathrm{LH}$ concentrations in the plasma of sheep (Messager et al., 2005). Furthermore, Kisspeptin-10 (Kp-10) stimulated circulating concentrations of LH in Holstein cows and ovariectomized Jersey cows, and interestingly the sensitivity of $\mathrm{LH}$ to exogenous $\mathrm{Kp}-10$ stimulation seems to be enhanced with lactation (Whitlock et al., 2010). Kisspeptin expression is structured by steroids as the quantity of $\mathrm{Kp}$ positive cells in the ARC increased in OVX ewes paralleled to intact ewes, the contradictory being found in the preoptic area (POA) Kp neurons (Smith et al.2007). Furthermore, the number of $\mathrm{Kp}$ positive cells in the arcuate nucleus (ARC) were reduced in OVX ewes on treatment with estrogen or progesterone (Smith et al., 2007). Fascinatingly, single nucleotide polymorphisms in the Kiss1 gene were associated with increased litter size in goats (An et al., 2013). The LH response to Kp-10 was greater in the late-follicular phase when matched with the luteal phase during the breeding season (Smith et al., 2011), and the influence of $\mathrm{Kp}-10$ on $\mathrm{LH}$ but not FSH, secretion, was more during the anoestrous season than in the luteal phase during the breeding season (Smith et al., 2009a).

\section{Consociates and actions of kisspeptin on GnRH neurons}

Kp-IR fibers were acknowledged in the POA region in ewes, where the GnRH neurons exist (Franceschini et al., 2006). Additionally, KpIR fibers were found to encompass from the ARC into the external neurosecretory segment of the Median Eminence (ME) (Pompolo et al., 2006) in both females (ewes: Smith et al 2011) and males (goat: Ohkura et al., 2009b). These terminals might be the basis for the kisspeptin that has been documented in the ewe hypophyseal portal blood (Smith et al., 2008). Kisspeptin might have a non-synaptic action at the ME level to initiate $\mathrm{GnRH}$ release. Electron microscopy has publicised that the axon terminals of kisspeptin neurons do in fact are in close contact with GnRH axon terminals in goats (Matsuyama et al., 
2011) and rats (Uenoyama et al., 2011). Hence, even though kisspeptin neurons may relate with either cell bodies or the axon terminals of $\mathrm{GnRH}$ neurons, the earlier is unlikely to be the foremost site of kisspeptin action in males.

GnRH neurons directly act on Kisspeptin to commence a sustained depolarization event. The capability of GnRH neurons to retort to kisspeptin signals is progressively synchronized, with the percentage of responsive $\mathrm{GnRH}$ neurons rising from $25 \%$ in the pre-pubertal period to more than $90 \%$ in adults. This elevation in $\mathrm{GnRH}$ responsiveness during the pre-pubertal period echoes an increase in Kiss1 gene expression (Han et al., 2005). Central Infusion of a GPR54 antagonist gridlocked or attenuated both pulsatile LH secretion (Goodman et al., 2012) and the E2induced LH surge (Smith et al., 2011) in ewes. Functional inactivation of GPR54 by chronic administration of potent GPR54 agonists totally eliminated LH pulses in male (Ohkura et al., 2011) and female goats (Wakabayashi et al., 2011), these studies clearly depicts that kisspeptin plays a crucial role in the control of both the pulsatile and surge modes of $\mathrm{GnRH}$ secretion.

\section{Deeds of kisspeptin on reproductive function}

Kisspeptin and puberty: The commencement of puberty is triggered by the stimulation of neurons in the forebrain which harvest a neuroendocrine substrate to stimulate $\mathrm{GnRH}$ (Saito et al., 2012). Studies in mammals specified that kisspeptin and GPR54 were crucial controllers of puberty due to the programmed increased in Kiss1 mRNA, GPR54 mRNA (only in females), which had been witnessed in the anteroventral periventicular nucleus (AVPV), the POA, and the ARC areas which would cause an upsurge in GPR54 sensitivity to kisspeptin (possibly due to increase in receptors at the cell surface). Studies on Kiss1R knockout mice illustrated that they do not attain the process of puberty and agonize severe shortfalls in their reproductive function in adulthood, e.g., sexual immaturity, smaller gonads, absence of spermatogenesis, low concentrations of gonadotropins and sex steroids, impaired ovulation, and therefore, irregular or absent cycling (Holmes. 2014). Male and female rodents show a remarkable rise in the hypothalamic expression levels of Kiss1 mRNA during puberty (Navarro et al., 2004). Stimulation of the kisspeptin system facilitates increased pulsatile and surge modes of GnRH from GnRH neurons then GnRH rouses the reproductive axis fetching about pubertal maturation via hypophyseal portal circulation to fuel the fabrication and release of gonadotropins such as luteinizing hormone (LH) and follicle-stimulating hormone (FSH) (Kadokawa et al., 2008a). It has been proposed that such changes in the expression levels of KISS1 mRNA possibly reflect not only in upsurge of neuronal activity during puberty, but also a possible mediation of kisspeptin on the neuroendocrine events prompting the commencement of puberty (Dungan et al., 2006). Close to puberty, and as a consequence of the increased adipose tissue in the body, greater amounts of leptin are on the rampage from the adipocytes, leading to higher levels of this hormone in blood (Vigil et al., 2013). Recent studies suggest that leptin surge would endorse kisspeptin secretion from kisspeptinergic neurons, and the latter hormone would bind to its GPR54 receptor in the GnRH-releasing neurons. Once stimulated, these would secrete higher amounts of GnRH, enhancing the release of FSH and LH from the adenohypophysis. Therefore it can be suggested that kisspeptin is a key factor triggering puberty

Kisspeptin mechanism on hypothalamic pituitary gonadal axis: Estrogen receptor- $\alpha$ $(\mathrm{ER} \alpha)$, Progesterone receptor (PR) and androgen receptor (AR) are expressed by 
Kisspeptin neurons, and therefore pose a potential relay feedback effects on the $\mathrm{GnRH}$ neuron (Hashizume et al., 2010). Researchers found that ovariectomy (OVX) and estrogen replacement in animals affected kisspeptin expression in the different region of the hypothalamus called by "Differential estrogen regulation" (Adachi et al., 2007).

Basically, there are two modes of GnRH secretion: a) estrogen-induced ovulatory surge of $\mathrm{GnRH} / \mathrm{LH}$, b) pulsatile, basal $\mathrm{GnRH} / \mathrm{LH}$ releasing modes. The prototype is welldeveloped in rodents. On one hand, the Kiss1 neurons in the AVPV are directly roused by estrogen effects via ER $\alpha$ (predominant in females). These neurons through GPR54 which is expressed on the cell bodies will stimulate GnRH neurons. This positive feedback of estrogen effects on AVPV Kiss1 neurons climaxes in the GnRH/LH surge, which generates the pre-ovulatory LH surge, which in turn triggers ovulation. On the other hand, the pulsatile $\mathrm{GnRH} / \mathrm{LH}$ release from ARC kisspeptin neurons (present in both female and male) energies tonic secretion of gonadotropin which mainly controls folliculogenesis and steroidogenesis. Additionally, it appears that positive feedback occurs at the level of GnRH cell bodies, with estrogen-responsive cells in the AVPV projecting directly to GnRH neurons, whereas negative feedback occurs primarily at the GnRH terminal level by an indirect (interneuronal) pathway (from estrogen-sensitive neurons in the ARC) (Smithet al., 2010).

Figure.1 A schematic illustration of the novel hypothalamic-pituitary-gonadal (HPG) axis. The two populations of kisspeptin neurons in the preoptic area (POA) and arcuate nucleus (ARC) are suggested to be located upstream of the gonadotropin-releasing hormone $(\mathrm{GnRH})$ neurons in the HPG axis and to control the surge and pulse modes of GnRH/luteinizing hormone (LH) secretion, respectively. Neurokinin B (NKB) likely plays a role in the pulse-generating mechanism of the ARC kisspeptin neurons. ME, median eminence; och, optic chiasm; Pit, pituitary; pt, pars tuberalis

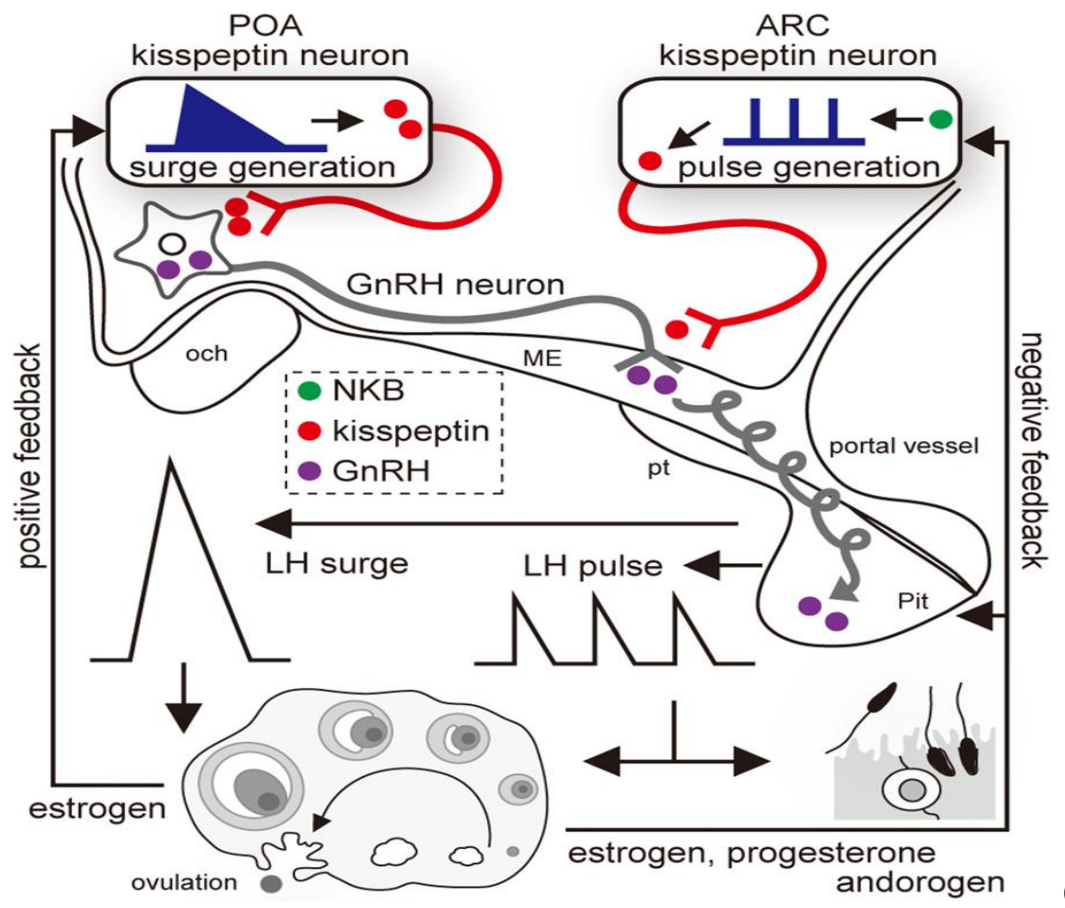

(Okamura et al., 2013) 
Kisspeptin: reproductive research in ruminants

Kp-10 was infused intravenously at 480 $\mathrm{nmol} / \mathrm{h}$ for $8 \mathrm{~h}$ in progesterone-primed cyclic ewes (Caraty et al., 2007). It appeared to increase LH surge within $2 \mathrm{~h}$ after initiation of Kp-10. These results recommend that kisspeptin may be used as a brand new tool for synchronization of ovulation. The immediate upsurge in LH secretion stirred by peripheral administration of the Kiss-1 peptide to OVX ewes appeared to imitate a straight action on the hypothalamus (Arreguin-Arevalo et al., 2007). Meanwhile, sheep are short-day breeders, Melatonin, a photoperiodic hormone triggers their reproductive activity. Throughout the nonbreeding season/ anoestrus, GnRH secretion is by both steroid-independent and steroiddependent mechanisms (Smith. 2009). Captivatingly, the estrogen hold on Kiss1 mRNA and kisspeptin protein expression within the ARC were superior throughout the non-breeding season in ewes (Smith et al., 2008). Hence, the core candidate to facilitate changes in feedback effect of estrogen seems to be Kisspeptin cells (Smith, 2009). In addition, a seasonal allowance in Kiss1 expression in OVX ewes in ARC region, significantly specifies that kisspeptin is basically convoluted in the seasonal change control in their reproductive function (Smithet al., 2007). In cattle, kisspeptin along with luteinizing hormone (LH), also excites growth hormone (GH) in OVX cows, which were injected with kisspeptin10 (Kp10) in different doses. In vitro analysis indicated that kisspeptin was relevant to the release of growth hormone (GH) and prolactin (PRL) as well as the release of gonadotropin in ruminants (Hashizume et al., 2010). One study showed that Kp10 treatment stimulated LH secretion from anterior pituitary cells in bovines (Ezzat et al., 2010). In OVX goats, the peripheral infusion of $\mathrm{Kp} 10$ stimulates
GnRH neurosecretion into hypophyseal portal circulation and the action of kisspeptin on $\mathrm{LH}$ releasing is mediated by $\mathrm{GnRH}$.

It is concluded as compared to last decade, emerging research confirms that the kisspeptin neuronal system shows a significant role as the gatekeeper of reproduction and thereby governs the secretion of GnRH secretion. Kiss1 genes primarily appear in the hypothalamus of ruminants and other mammals to deliver negative and positive feedback directive of $\mathrm{GnRH}$ exudation by gonadal steroids. Secretion of the kisspeptin hormone exerts neuroendocrine effects of elementary importance in the activation of the hypothalamic-hypophyseal-gonadal axis. In ruminants, the kisspeptin cells in the ARC are poised to play a role in the steroid negative feedback control of GnRH. Detection of kisspeptin may additionally offer therapeutic potential. The kisspeptin system has provided a new window to develop substitute treatments for disorders of reproduction branded by low gonadotrophins or anovulation and also for the development of high potency analogs parallel to those already in place for GnRH that may be helpful for conditions during downregulation of reproductive activity is desirable.

\section{References}

Adachi S, Yamada S, Takatsu Y, Matsui H, Kinoshita M, Takase K, Sugiura H, Ohtaki T, Matsumoto H, Uenoyama Y, Tsukamura H, Inoue K, Maeda K-I. 2007. Involvement of anteroventral periventricular metastin/kisspeptin neurons in estrogen positive feedback action on luteinizing hormone release in female rats. The Journal of Reproduction and Development 53, 367-378.

An X, Ma T, Hou J, Fang F, Han P, Yan Y, et 
al., 2013. Association analysis between variants in KISS1 gene and litter size in goats. BMC Genet. 14:63-8

Arreguin-Arevalo JA, Lents CA, Farmerie TA, Nett TM and Clay CM 2007. KiSS-1 peptide induces release of $\mathrm{LH}$ by a direct effect on the hypothalamus of ovariectomized ewes. Anim Reprod Sci. 101: 265-275.

Caraty A, Smith JT, Lomet D, Ben Said S, Morrissey A, Cognie J, et al., 2007. Kisspeptin synchronizes preovulatory surges in cyclical ewes and causes ovulation in seasonally acyclic ewes. Endocrinology; 148: 5258-67.

Caraty A, Smith JT, Lomet D, Ben Said S, Morrissey A, Cognie J, et al., 2007. Kisspeptin synchronizes preovulatory surges in cyclical ewes and causes ovulation in seasonally acyclic ewes. Endocrinology. 148: 5258-67.

Dungan HM, Clifton DK, Steiner RA. 2006. Mini review: kisspeptin neurons as central processors in the regulation of gonadotropin-releasing hormone secretion. Endocrinology; 147:1154

Ezzat AA, Saito H, Sawada T, Yaegashi T, Goto Y, Nakajima Y, Jin J, Yamashita T, Sawai K and Hashizume T 2010. The role of sexual steroid hormone in the direct stimulation by Kisspeptin10 of the secretion of luteinizing hormone, follicle-stimulating hormone and prolactin from bovine anterior pituitary cells. Anim Reprod Sci. 121: 267-272.

Franceschini I, Lomet D, Cateau M, Delsol G, Tillet Y, Caraty A. 2006. Kisspeptin immunoreactive cells of the ovine preoptic area and arcuate nucleus coexpress estrogen receptor alpha. Neuroscience Letters 401, 225-230.

Goodman RL, Lehman MN. 2012. Kisspeptin neurons from mice to men: similarities and differences. Endocrinology 153,
5105-5118.

Gottsch ML, Cunningham MJ, Smith JT, Popa SM, Acohido BV, Crowley WF, Seminara S, Clifton DK, Steiner RA. 2004. A role for kisspeptin in the regulation of gonadotropin secretion in the mouse. Endocrinology 145, 4073- 4077

Han SK, Gottsch ML, Lee KJ, Popa SM, Smith JT, Jakawich SK, Clifton DK, Steiner RA and Herbison AE 2005. Activation of gonadotropin- releasing hormone neurons by kisspeptin as a neuroendocrine switch for the onset of puberty. J Neurosci. 25: 11349-11356.

Hashizume T, Saito H, Sawada T, Yaegashi T, Ezzat AA, Sawai K, Yamashita T. 2010. Characteristics of stimulation of gonadotropin secretion by kisspeptin10 in female goats. Animal Reproduction Science 118, 37-41.

Holmes D. 2014, Metabolism: Kisspeptin signaling linked to obesity. Nat Rev Endocrinol., 10:511.

Lee JH, Miele ME, Hicks DJ, Phillips KK, Trent JM, Weissman BE, Welch DR. 1996. KiSS-1, a novel human malignant melanoma metastasissuppressor gene. Journal of the National Cancer Institute 88, 17311737

Matsuyama S, Ohkura S, Mogi K, Wakabayashi Y, Mori Y, Tsukamura H, Maeda K, Ichikawa M, Okamura H. 2011. Morphological evidence for direct interaction between kisspeptin and gonadotropin-releasing hormone neurons at the median eminence of the male goat: an immune electron microscopic study. Neuro endocrinology, 94: 323-332.

Messager S, Chatzidake EE, Ma D, Hendrick AG, Zahn D, Dixon J, et al., 2005. Kisspeptin directly stimulates gonadotropin-releasing hormone release via $G$ protein-coupled receptor 
54. Proc Natl Acad. Sci. U S A; 102: 1761-6.

Messager S, Chatzidaki EE, Ma D, Hendrick AG, Zahn D, Dixon J, Thresher RR, Malinge I, Lomet D, Carlton MBL, Colledge WH, Caraty A, Aparicio SA. 2005. Kisspeptin directly stimulates gonadotropin-releasing hormone release via $\mathrm{G}$ protein-coupled receptor 54. Proceedings of the National Academy of Sciences of the United States of America 102, 1761-1766.

Navarro VM, Castellano JM, FernándezFernández R, et al., 2004. Developmental and hormonally regulated messenger ribonucleic acid expression of KiSS-1 and its putative receptor, GPR54, in rat hypothalamus and potent luteinizing hormonereleasing activity of KiSS-1 peptide. Endocrinology; 145:456

Ohkura S, Takase K, Matsuyama S, Mogi K, Ichimaru T, Wakabayashi Y, Uenoyama Y, Mori Y, Steiner RA, Tsukamura H, Maeda K-I OH. 2009b. Gonadotrophin- releasing hormone pulse generator activity in the hypothalamus of the goat. Journal of Neuroendocrinology 21, 813-821.

Ohkura S, Tanaka T, Kuroiwa T, Wakabayashi Y, Ohtaki T, Kusaka M, Okamura H. 2011. Effects of metastin/ kisspeptin analog, TAK-683, on luteinizing hormone secretion in peripheral plasma, and gonadotropinreleasing hormone secretion in the pituitary portal circulation in goats. Endocrine Reviews 32, P2-273.

Okamura, H., Yamamura, T., and Wakabayashi, Y. (2013). Kisspeptin as a master player in the central control of reproduction in mammals: An overview of kisspeptin research in domestic animals. Animal Science Journal, 84(5), 369-381.

Pompolo S, Pereira A, Estrada KM, Clarke IJ.
2006. Colocalization of kisspeptin and gonadotropin-releasing hormone in the ovine brain. Endocrinology. 147:80410

Roseweir AK, Kauffman AS, Smith JT, Guerriero KA, Morgan K, PieleckaFortuna J, et al., 2009. Discovery of a potent kisspeptin antagonists delineate physiological mechanisms of gonadotropin regulation. J Neuro sci. 29:3920-9.

Seminara SB, Messager S, Chatzidaki EE, Thresher RR, Acierno JS, Shagoury JK, Bo-Abbas Y, Kuohung W, Schwinof KM, Hendrick AG, Zahn D, Dixon J, Kaiser UB, Slaugenhaupt SA, Gusella JF, O'Rahilly S, Carlton MB, Crowley WF Jr, Araricio SA, Colledge WH. 2003. The GPR54 gene as a regulator of puberty. The New England Journal of Medicine 349, 1614-1627.

Smith JT 2009. Sex steroid control of hypothalamic Kiss1 expression in sheep and rodent: Comparative aspects. Peptides. 30: 94-102.

Smith JT, Clay CM, Caraty A, Clarke IJ. 2007. KiSS-1 messenger ribonucleic acid expression in the hypothalamus of the ewe is regulated by sex steroids and season. Endocrinology. 148:11507

Smith JT, Li Q, Yap KS, Shahab M, Roseweir AK, Millar RP, et al., 2011. Kisspeptin is essential for the full preovulatory LH surge and stimulates $\mathrm{GnRH}$ release from the isolated ovine median eminence. Endocrinology. 152:1001-12

Smith JT, Rao A, Pereira A, Caraty A, Millar RP, Clarke IJ. 2008. Kisspeptin is present in ovine hypophysial portal blood but does not increase during the preovulatory luteinizing hormone surge: evidence that gonadotropes are not direct targets of kisspeptin in vivo. 
Endocrinology. 149:1951-9.

Smith JT, Saleh SNH, Clarke IJ. 2009a. Seasonal and cyclical change in the luteinizing hormone response to kisspeptin in the ewe. Neuroendocrinology 90, 283-291

Smith MS, True C, Grove KL. 2010. The neuroendocrine basis of lactationinduced suppression of GnRH: role of kisspeptin and leptin. Brain Res 1364: $139-152$

Uenoyama Y, Inoue N, Pheng V, Homma T, Takase K, Yamada S, Ajiki K, Ichikawa M, Okamura H, Maeda K-I, Tsukamura H. 2011. Ultrastructural evidence of kisspeptin-gonadotrophinreleasing hormone $(\mathrm{GnRH})$ interaction in the median eminence of female rats: implication of axoaxonal regulation of
GnRH release. Journal of Neuroendocrinology 23, 863-870.

Vigil P. 2013. La Fertilidad de la Pareja Humana, Cuarta Edición Ampliada, Santiago, Ediciones Universidad Católica de Chile, pp 48-50

Wakabayashi Y, Yamamura T, Ohkura S, Tanaka T, Kusaka M, Okamura $\mathrm{H}$. 2011. Effects of chronic administration of a metastin analog, TAK-683, on the GnRH pulse generator activity in ovariectomized goats. Endocrine Reviews 32, P2-264.

Whitlock BK, Daniel JA, Wilborn RR, Maxwell HS, Steele BP, Sartin JL. 2010. Interaction of kisspeptin and the somatotropic axis. Neuroendocrinology. 92:178-88.

\section{How to cite this article:}

Shashank, C.G., N. Anand Kumar and Banakar, P.S. 2018. Mystic Effects of Kisspeptin in Reproduction of Livestock. Int.J.Curr.Microbiol.App.Sci. 7(07): 2140-2147. doi: https://doi.org/10.20546/ijcmas.2018.707.251 